\title{
Analitikus módszer szilárdtestekben lézerimpulzus által elmozdított töltések kiszámítására
}

\author{
Magashegyi István ${ }^{1}$, Földi Péter ${ }^{1,2}$ \\ ${ }^{1}$ Szegedi Tudományegyetem, Elméleti Fizikai Tanszék, Tisza L. krt. 84-86, 6720 Szeged \\ ${ }^{2}$ ELI-ALPS, ELI-HU Non-Profit Kft., Wolfgang Sandner utca 3, 6728 Szeged
}

DOI: https://doi.org/10.14232/kvantumelektronika.9.25

\section{Bevezetés}

Szilárdtestek optikai gerjesztésének modellezésére jól kidolgozott elméleti módszerek léteznek, különösen az alacsony intenzitástartományban, Tankönyvekből ismert pl. hogy félvezetôk közel monokromatikus megvilágítása esetén csak olyan hullámhosszakon jönnek létre sávátmenetek, amelyeknél a gerjesztô fotonenergia nagyobb, mint a tiltott sáv szélessége. Ezzel szemben, a femtoszekundumos tartományba esố impulzushosszak és a GV/m csúcstérerősségek egy olyan tartományt jelentenek, amelyben akár több elektronvoltnyi szélességú tiltott sávok is áthidalhatók közeli infravörös gerjesztéssel, anélkül, hogy maga a szilárdtest struktúra visszafordíthatatlan sérülést szenvedne. Kísérletileg pl. kristályos $\mathrm{ZnO}$ [1,2] és amorf $\mathrm{SiO}_{2}$ [3] esetében is detektáltak sávátmenettel járó jelenségeket; ezekben az esetekben tipikus fotonenergiák és a tiltott sáv szélességének viszonya miatt "többfotonos" folyamatokról szokás beszélni. Ebben a tartományban az alkalmazott modellek jelenleg még sokkal kevésbé letisztultak.

A sávátmenetek indukálása mellett az intenzív lézerimpulzusok a szilárdtestekben áramokat is létrehoznak. Ezek az áramok időben olyan gyorsan oszcillálnak [4], hogy azt a jelenlegi detektorok nem képesek feloldani. Ezzel szemben időintegráljuk - azaz a lézerimpulzus által elmozdított töltés - már mérhetô. A továbbiakban egy olyan elméleti módszert mutatunk be, amelynek segítségével ki tudjuk számítani ezt a töltést.

\section{Modell}

Tételezzük fel azt, hogy kezdetben a szilárdtest termikus egyensúlyban van, így az eredő áram nulla [5]. Ez úgy adódik, hogy $\Psi_{n}(\mathbf{k}, \mathbf{r})$ Bloch-állapotokat tekintve (ahol $\mathbf{k}$ az állapot síkhullám részének a kitevőjében szerepel, $n$ pedig a sávindex), egyensúlyban $\Psi_{n}(\mathbf{k}, \mathbf{r})$ és $\Psi_{n}(-\mathbf{k}, \mathbf{r})$ azonos mértékben populált, az általuk hordozott áramok pedig azonos nagyságúak, de ellentétes irányúak. A továbbiakban egyelektron képben dolgozva, egyetlen $\Psi_{n_{0}}\left(\mathbf{k}_{0}, \mathbf{r}\right)$ kezdőállapotból induló dinamikára koncentrálunk. Az optikai gerjesztés hatására ez a Bloch-állapotoknak egy szuperpozíciójába megy át, amit a következő alakba írunk:

$$
\Psi(\mathbf{r}, t)=\Psi_{n_{0}}\left(\mathbf{k}_{0}, \mathbf{r}, t\right)+\Phi(\mathbf{r}, t)=\Psi_{n_{0}}\left(\mathbf{k}_{0}, \mathbf{r}, t\right)+\sum_{n} \int_{B Z} \phi_{n}(\mathbf{k}) \Psi_{n}(\mathbf{k}, \mathbf{r}, t) d^{3} \mathbf{k},
$$

azaz leválasztjuk az $E_{n_{0}}(\mathbf{k})=\hbar \omega_{n_{0}}(\mathbf{k})$ diszperziós reláció ismeretében a triviális időfüggéssel

$$
\Psi_{n_{0}}\left(\mathbf{k}_{0}, \mathbf{r}, t\right)=\Psi_{n_{0}}\left(\mathbf{k}_{0}, \mathbf{r}\right) e^{-i \omega_{n_{0}}(\mathbf{k}) t}
$$

jellemezhető kezdőállapot. (Az (1) egyenletben a BZ index arra utal, hogy az integrálást az első Brillouin zónára kell elvégezni.) Ezt szemlélteti egydimenzióban az 1. ábra.

Itt érdemes megjegyezni, hogy szigorúan véve a dipólközelítést, az (1) egyenlet jobb oldalán az integrál csak olyan tagokat tartalmaz, amelyek esetén k megegyezik a kiinduló állapotéval. ("Az 


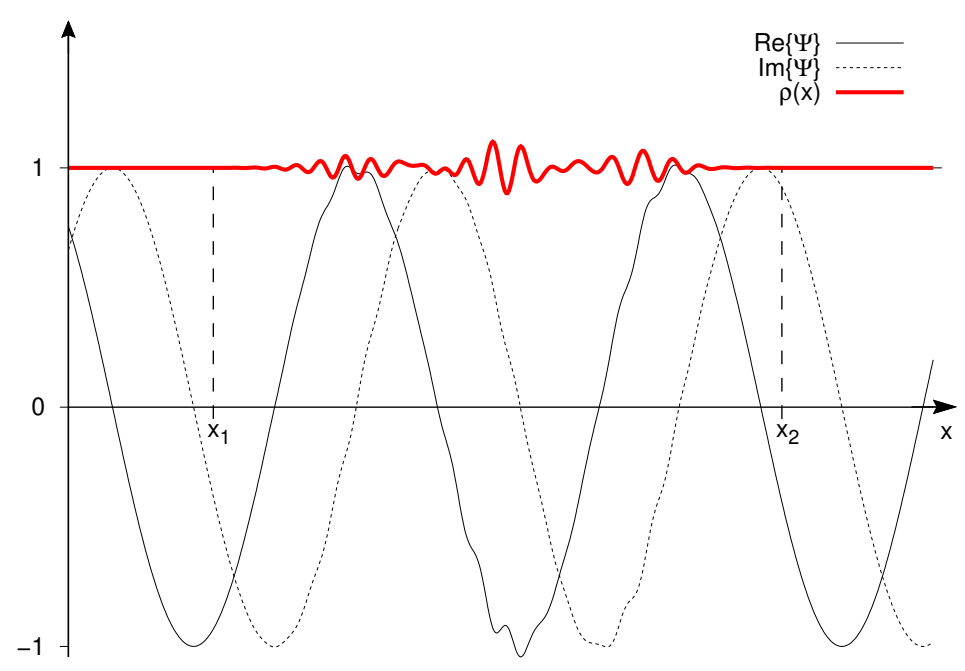

1. ábra. Lézertér hatása az elemi cellára átlagolt Bloch-hullámfüggvényre kvadratikus diszperziós reláció esetén. A piros görbe a $\rho(x)=|\Psi(x)|^{2}$ súrúséget mutatja a lézerimpulzussal történő kölcsönhatás után, illetve láthatjuk $\Psi(x)$ valós és képzetes részét is.

optikai átmenetek vertikálisak", ami a mértékválasztástól függetlenül igaz [6].) A dipólközelítés érvényességét ahhoz szokás kötni, hogy az elemi cella lineáris mérete sokkal kisebb a hullámhossznál. Ez természetesen infravörös tartományban mindenképpen igaz, ugyanakkor a lokális gerjesztés mindenképpen okoz kicsiny eltéréseket a pusztán vertikális átmenetek esetétől.

Ezután a szokásos nemreativisztikus áramsûrúséget

$$
\mathbf{j}(\mathbf{r}, t)=\frac{e \hbar}{m} \operatorname{Im}\left\{\Psi^{*}(\mathbf{r}, t) \nabla \Psi(\mathbf{r}, t)\right\}
$$

számítjuk ki az (1) állapotban. Az egyszerúség kedvéért a továbbiakban legyen $e=1$. Csak az $x$ komponenst kiírva azt kapjuk hogy:

$$
\begin{aligned}
& j_{x}(\mathbf{r}, t)=\underbrace{\frac{\hbar}{m} \operatorname{Im}\left\{\Psi_{n_{0}}^{*}\left(\mathbf{k}_{0}, \mathbf{r}, t\right) \frac{\partial \Psi_{n_{0}}\left(\mathbf{k}_{0}, \mathbf{r}, t\right)}{\partial x}\right\}}_{j_{0}(\mathbf{r}, t)}+\underbrace{\frac{\hbar}{m} \operatorname{Im}\left\{\Phi(\mathbf{r}, t) \frac{\partial \Phi(\mathbf{r}, t)}{\partial x}\right\}}_{j_{\Phi}(\mathbf{r}, t)} \\
& +\underbrace{\frac{\hbar}{m} \operatorname{Im}\left\{\Psi_{n_{0}}^{*}\left(\mathbf{k}_{0}, \mathbf{r}, t\right) \frac{\partial \Phi(\mathbf{r}, t)}{\partial x}+\Phi^{*}(\mathbf{r}, t) \frac{\partial \Psi_{n_{0}}(\mathbf{r}, t)}{\partial x}\right\}}_{j_{c}(\mathbf{r}, t)} .
\end{aligned}
$$

Itt a $j_{0}(\mathbf{r}, t)$ tag tisztán a $\Psi_{n_{0}}\left(\mathbf{k}_{0}, \mathbf{r}, t\right)$ állapothoz tartozó áramsûrúség, $j_{\Phi}(\mathbf{r}, t)$ ugyanígy $\Phi(\mathbf{r}, t)$-hez tartozik, a $j_{c}(\mathbf{r}, t)$ kereszttag pedig a két korábbi állapot közötti szuperpozíció eredménye.

Tegyük fel, hogy a töltés meghatározására szolgáló detektorok $t=0$-ban kapcsolnak be. Természetesen a $Q_{0}$ töltés (ami $j_{0}$ időintegrálja) lineárisan növekszik. Ugyanakkor ha elvégezzük a 
számítást a kezdeti állapothoz képest ellentétes k esetén is, akkor ez a tag kiesik. Így elegendő a

$$
\begin{aligned}
Q_{d}(\mathbf{r}, t \rightarrow \infty) & =Q_{d}(\mathbf{r})=\int_{0}^{\infty} j(\mathbf{r}, t)-j_{0}(\mathbf{r}, t) \mathrm{d} t \\
& =\underbrace{\int_{0}^{\infty} j_{\Phi}(\mathbf{r}, t) \mathrm{d} t}_{Q_{\Phi}(\mathbf{r})}+\underbrace{\int_{0}^{\infty} j_{c}(\mathbf{r}, t) \mathrm{d} t}_{Q_{c}(\mathbf{r})} .
\end{aligned}
$$

különbségre koncentrálnunk, ami teljes egészében a lézerimpulzus hatására jön létre.

\section{A lézerimpulzus által elmozdított össztöltés analitikus kiszámítása}

A könnyebb átláthatóság kedvéért a továbbiakban egy dimenzióban (1D) vizsgáljuk a kérdést. Elsőként tekintsük $Q_{\Phi}(x)$-t, azaz $Q_{\Phi}(\mathbf{r}) 1 \mathrm{D}$ verzióját:

$$
Q_{\Phi}(x)=\frac{\hbar}{m} \operatorname{Im}\left\{\sum_{n, n^{\prime}} \int_{0}^{\infty} \int_{B Z} \int_{B Z} e^{-i\left[\omega_{n^{\prime}}\left(k^{\prime}\right)-\omega_{n}(k)\right] t} \phi_{n}^{*}(k) \phi_{n^{\prime}}\left(k^{\prime}\right) \Psi_{n}^{*}(k, x) \frac{\partial \Psi_{n^{\prime}}\left(k^{\prime}, x\right)}{\partial x} \mathrm{~d} k \mathrm{~d} k^{\prime} \mathrm{d} t\right\} .
$$

Ez az integrál egyszerúsödik, ha alkalmazzuk az

$$
\int_{0}^{\infty} e^{-i\left[\omega_{n^{\prime}}\left(k^{\prime}\right)-\omega_{n}(k)\right] t} \mathrm{~d} t=\pi \delta\left[\omega_{n^{\prime}}\left(k^{\prime}\right)-\omega_{n}(k)\right]-\frac{i}{\omega_{n^{\prime}}\left(k^{\prime}\right)-\omega_{n}\left(k^{\prime}\right)},
$$

összefüggést, ahol a jobb oldalon Dirac-delta jelenik meg és Cauchy-féle főérték értendő. Érdemes bevezetni a $Q_{\Phi}(x)=Q_{\Phi}^{\prime}(x)+Q_{\Phi}^{\prime \prime}(x)$, jelölést, ahol $Q_{\Phi}^{\prime}(x)$ esetén az (6) egyenlet jobb oldalának elsô tagját helyettesítjük az (5) egyenletbe, míg $Q_{\Phi}^{\prime \prime}(x)$ tartalmazza a főrtékintegrált.

A továbblépéshez szükség van arra, hogy legalább kvalitaív képünk legyen a rendszer diszperziós relációjáról. Az egyszerüség kedvéért tételezzük fel, hogy a tiltott sávok direktek, azaz $\delta\left[\omega_{n^{\prime}}\left(k^{\prime}\right)-\right.$ $\omega_{n}(k)$ ] csak azonos $n$ és $n^{\prime}$ sávindexek esetén ad nem nulla járulékot. Az $\omega_{n}\left(k^{\prime}\right)=\omega_{n}(k)$ egyenlőség triviálisan igaz a $k=k^{\prime}$ esetben, de természetesen nem ez az egyetlen lehetőség. Bloch-elektronok esetén fennáll, hogy $\omega_{n}(k)=\omega_{n}(-k)$, így a $-k=k^{\prime}$ is megoldása az egyenlőségnek. Az egyszerúség kedvéért a továbbiakban csak ezt a két lehetőséget tekintjük. Így azt kapjuk, hogy

$$
\begin{aligned}
Q_{\Phi}^{\prime}(x) & =\frac{\hbar}{m} \operatorname{Im}\left\{\pi \sum_{n} \int_{B Z} \frac{\left|\phi_{n}(k)\right|^{2}}{\left|\omega_{n}^{\prime}(k)\right|} \Psi_{n}^{*}(k, x) \frac{\partial \Psi_{n}(k, x)}{\partial x} \mathrm{~d} k\right. \\
& \left.+\pi \sum_{n} \int_{B Z} \frac{\phi_{n}^{*}(k) \phi_{n}(-k)}{\left|\omega_{n}^{\prime}(-k)\right|} \Psi_{n}^{*}(k, x) \frac{\partial \Psi_{n}(-k, x)}{\partial x} \mathrm{~d} k\right\},
\end{aligned}
$$

ahol $\omega_{n}^{\prime}(k)=\left.\frac{\omega_{n}\left(k^{\prime}\right)}{\partial k^{\prime}}\right|_{k^{\prime}=k}$, azaz a Bloch-elektronokhoz tartozó sebesség az $n$-edik sávban. Mivel $\Psi_{n}(-k, x)=\Psi_{n}^{*}(k, x)$, a második tag képzetes része eltúnik, így az nem ad járulékot $Q_{\Phi}-$ hez. Ha átlagolunk egy, az $x$-et tartalmazó, $a$ hosszúságú elemi cellára a

$$
\overline{Q_{\Phi}^{\prime}}(x)=\frac{1}{a} \int_{x-a / 2}^{x+a / 2} Q_{\Phi}^{\prime}(s) d s
$$


módon, akkor felhasználva az

$$
\frac{1}{m} \int_{0}^{a} \Psi_{n}^{*}(k, x)(-i \hbar) \frac{\partial \Psi_{n}(k, x)}{x} d x=\frac{\omega_{n}^{\prime}(k)}{N}
$$

összefüggést, írhatjuk, hogy

$$
\overline{Q_{\Phi}^{\prime}}=\frac{\pi}{L} \sum_{n} \int_{B Z} \operatorname{sgn}\left[\omega_{n}^{\prime}(k)\right]\left|\phi_{n}(k)\right|^{2} \mathrm{~d} k .
$$

Itt $N$ az elemi cellák számát jelenti, $L=N a$ pedig az egydimanziós kristály teljes hossza.

A $Q_{\Phi}^{\prime \prime}$ integrál kiszámításához az integrandusz, mint komplex függvény analitikus tulajdonságainak ismeretére van szükség. Ez természetesen általában (különösen, ha a $\phi_{n}(k)$ "kifejtési együtthatókat" numerikusan nyerjük) nem ismert. Fizikailag feltehetjük, hogy $\phi_{n}(k)$ minden sávra korlátos tartójú $k$-ban. Ha emellett még az is igaz, hogy a teljes integrandusz analitikus a komplex $k$ síkon (kivéve a valós tengelyt), akkor $Q_{\Phi}^{\prime \prime}$, mint kontúrintegrál, kiszámítható a kölcsöhatási tartománytól távol eső detektorok esetére:

$$
\begin{aligned}
& \overline{Q_{\Phi}}(x \rightarrow \infty)=\frac{\pi}{L}\left(\sum_{n} \int_{B Z}\left(1+\operatorname{sgn}\left[\omega^{\prime}(k)\right]\left|\phi_{n}(k)\right|^{2} \mathrm{~d} k\right)\right. \\
&=\frac{2 \pi}{L} \sum_{n} \int^{+}\left|\phi_{n}(k)\right|^{2} \mathrm{~d} k, \\
& \overline{Q_{\Phi}}(x \rightarrow-\infty)=-\frac{2 \pi}{L} \sum_{n} \int^{-}\left|\phi_{n}(k)\right|^{2} \mathrm{~d} k .
\end{aligned}
$$

Ezekben az egyenletekben a + illetve - felső indexek a Brillouin-zóna azon tartományára történő integrálást jelentenek, ahol $\omega_{n}^{\prime}(k)$ pozitív illetve negatív. Mindez intuitívan azt jelenti, hogy a lézer által keltett $\Phi(x)$ hullámcsomag a pozitív (negatív) irányban azzal arányos töltést szállít, amennyi ebben a szuperpozícióban a pozitív (negatív) sebességú komponensek aránya. Azt is fontos észrevenni, hogy az egyes sávok járulékai függetlenek egymástól.

Az interferenciából származó $Q_{c}$ töltést hasonló lépéseket követve számíthatjuk ki. Összegezve az eredményt, a teljes, cellára átlagolt $\overline{Q_{d}}$ töltésre, nagy, pozitív $x$ értékek esetén adódik:

$$
\overline{Q_{d}}(x \rightarrow \infty)=\frac{2 \pi}{L} \sum_{n} \int^{+}\left|\phi_{n}(k)\right|^{2} \mathrm{~d} k+ \begin{cases}\frac{2 \pi}{L} \operatorname{Re}\left\{\phi_{n_{0}}\left(k_{0}\right)\right\} & \text { ha } \omega_{n_{0}}^{\prime}\left(k_{0}\right)>0 \\ 0 & \text { egyébként }\end{cases}
$$

míg a negatív irányban

$$
\overline{Q_{d}}(x \rightarrow \infty)=-\frac{2 \pi}{L} \sum_{n} \int^{-}\left|\phi_{n}(k)\right|^{2} \mathrm{~d} k- \begin{cases}\frac{2 \pi}{L} \operatorname{Re}\left\{\phi_{n_{0}}\left(k_{0}\right)\right\} & \text { ha } \omega_{n_{0}}^{\prime}\left(k_{0}\right)<0 \\ 0 & \text { egyébként }\end{cases}
$$

Érdemes megjegyezni, hogy - bár a fenti két egyenletből nem látszik azonnal - a (13) és (14) egyenletekkel adott limeszek megegyeznek egymással. Ez analitikusan is belátható, ha a kontinuitási egyenletből indulunk ki, és észrevesszük, hogy lokális gerjesztés esetén, a kölcsönhatási tartománynál észrevehetôen nagyobb intervallumot tekintve, a lézertér hatása nem változtatja meg az intervallumon belüli elektronsürúséget. 


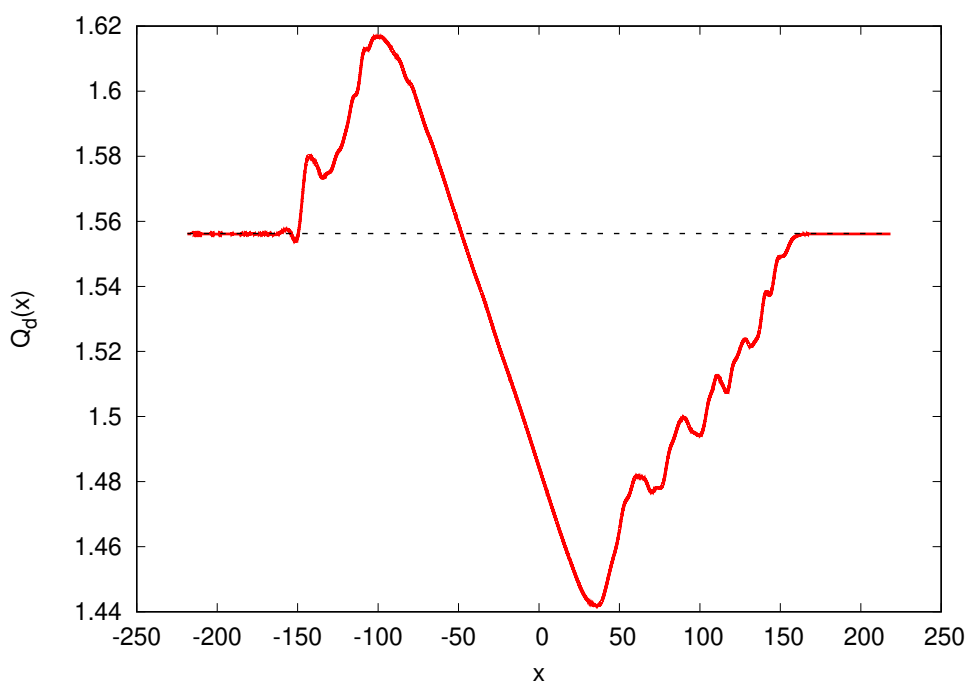

2. ábra. A $Q_{d}(x)$ mennyiség (önkényes egységekben) két, kvadratikus diszperzióval rendelkező sáv numerikusan számolt gerjesztése után. Ax $x$ tengelyen az egység az elemi cella hossza, $a$. A szaggatott vonal a (13) és (14) egyenleteknek megfelelő eredmény. A paraméterek: A lézerimpulzus központi hullámhossza $800 \mathrm{~nm}$, csúcstérerôssége $1 \mathrm{GV} / \mathrm{m}$, hossza 10 optikai ciklus. A tiltott sáv szélessége $3 \mathrm{eV}, k_{0} a=0.1$.

A (13) és (14) egyenletekkel adott eredményeinket több módon is ellenôriztük, és minden esetben érvényesnek találtuk. Kvadratikus diszperzió esetén, a síkhullámra szuperponált Gauss hullámcsomag esete analitikusan megoldható, és a (13) és (14) egyenletekkel adott határértékeket adja. A 2. ábra numerikus eredményt mutat, amikor a lézertér hatását a példa kedvéért két sáv figyelembe vételével számítottuk ki, és aztán direkt módon kiszámítottuk az egyes pontokon áthaladó áram integrálját a numerikusan értelemben vett hosszú idejű határesetben. Amint látható, a nagy $|x|$ értékekre érvényes határeset nagyon jó közelítéssel megegyezik a (13) és (14) eredményekkel.

\section{4. Összefoglalás}

Ebben a munkában a szilárdtestekben lézertérrel keltett áramokkal kapcsolatos eredményeinket foglaltuk össze. Megmutattuk, hogy ismerve az anyagi rendszer állapotát a kölcsönhatás után, a lézerimpulzus által elmozdított összes töltés analitikusan kiszámítható. Ez az eredmény jó kiindulópontot szolgáltat ahhoz, hogy elméleti úton megvizsgálhassuk, a lézertér paraméterei milyen mértékben határozhatók meg az általa elmozdított töltés megmérésével.

\section{Köszönetnyilvánítás}

A szerzők köszönik a Fehér Lászlónak és Papp Györgynek a hasznos konzultációkat.

A projekt az Európai Unió támogatásával, az Európai Szociális Alap társfinanszírozásával valósul meg. EFOP-3.6.2-16-2017-00005-Ultragyors fizikai folyamatok atomokban, molekulákban, nanoszerkezetekben és biológiai rendszerekben.

Munkánkat támogatták továbbá a TUDFO/47138-1/2019-ITM FIKP és a GINOP-2.3.2-15-201600036 számú pályázatok. Magát az ELI-ALPS projektet (GINOP-2.3.6-15-2015-00001) az Európai Unió és az Európai Regionális Fejlesztési Alap támogatja. 


\section{Irodalom}

[1] S. Ghimire, A. D. DiChiara, E. Sistrunk, P. Agostini, L. F. DiMauro és D. A. Reis, Nat. Physics 7, $138(2011)$

https://doi.org/10.1038/nphys1847

[2] S. Ghimire, A. D. DiChiara, E. Sistrunk, U. B. Szafruga, P. Agostini, L. F. Di- Mauro és D. A. Reis, Phys. Rev. Lett. 107, 167407 (2011)

https://doi.org/10.1103/PhysRevLett.107.167407

[3] A. Schiffrin, T. Paasch-Colberg, N. Karpowicz, V. Apalkov et al., Nature 493, 70 (2013) https://doi.org/10.1038/nature11567

[4] I Magashegyi, L. Zs. Szabó, P. Földi, J. Opt. Soc. Am. B 35, A116 (2018) https://doi.org/10.1364/JOSAB.35.00A116

[5] P. Földi, M. G. Benedict, V. S. Yakovlev:, New. J. Phys.. 15, 063019 (2013) https://doi.org/10.1088/1367-2630/15/6/063019

[6] P. Földi, Phys. Rev. B 96, 035112 (2017)

https://doi.org/10.1103/PhysRevB.96.035112 